\title{
Serum and liver HCV RNA levels in patients with chronic hepatitis C: correlation with clinical and histological features
}

\author{
L De Moliner, P Pontisso, G L De Salvo, L Cavalletto, L Chemello, A Alberti
}

\begin{abstract}
Background-Liver disease in chronic hepatitis $\mathrm{C}$ virus (HCV) infection ranges from minimal lesions to liver cirrhosis, eventually evolving to hepatocellular carcinoma. Whether and how HCV determines the different clinical and histological manifestations of the disease is not fully understood.

Aims-To verify whether the amount of virus in individual patients could be related to the severity of liver injury.

Patients and methods-Levels of $\mathrm{HCV}$ RNA were measured in serum in 96 consecutive patients with chronic hepatitis type $C$ using a signal amplification assay. The relation between viraemic values and the corresponding viral load in the liver was assessed in a subgroup of 21 patients in whom HCV RNA was measured in serum samples and liver specimens obtained at the same time.

Results-A positive correlation was observed between the amount of viral nucleic acid in the two compartments, indicating that levels of viraemia reflect the amount of virus present in the liver. Viral load did not correlate with aminotransferase activities nor with histological diagnosis, and serum and liver levels of HCV RNA were not significantly different in patients infected by the various $\mathrm{HCV}$ genotypes.

Conclusions-Measurement of HCV replication in serum is a mirror of viral replication in the liver. The extent of replicative activity of $\mathrm{HCV}$ does not seem to play a role in the modulation of the associated hepatic disease.

(Gut 1998;42:856-860)
\end{abstract}

Department of Clinical and Experimental

Medicine, University

of Padova, Italy

L De Moliner

P Pontisso

G L De Salvo

L Cavalletto

L Chemello

A Alberti

Correspondence to:

Dr P Pontisso, Clinica

Medica 5-Dipartimento di

Medicina Clinica

Sperimentale, Via Giustiniani

2, 35128 Padova, Italy.

Accepted for publication 19 January 1998

The spectrum of liver disease in patients infected with hepatitis $\mathrm{C}$ virus (HCV) ranges from minimal lesions in $\mathrm{HCV}$ asymptomatic carriers to chronic hepatitis of variable severity, cirrhosis, and hepatocellular carcinoma. Different host and viral factors have been postulated to influence the clinical outcome of the disease. Discrete genomic variations may affect expression of viral proteins, ${ }^{12}$ and possibly efficiency of replication. Whether viral load in liver tissue and in the circulation has a role in determining the extent of liver disease is still controversial. $^{3-6}$ Most published studies have considered HCV RNA levels in serum, while less data are available on the amount of viral nucleic acid in the liver and on its relation with viraemia. $^{7-9}$ To assess these issues, we have evaluated serum HCV RNA levels in relation to clinical and histological findings in a large series of patients with chronic hepatitis C; in a subgroup, simultaneous evaluation of viral load was carried out in liver specimens obtained at the same time.

\section{Patients and methods}

PATIENTS

Ninety six consecutive patients (58 men, 38 women, mean (SD) age 46.5 (18.5) years) with chronic $\mathrm{HCV}$ infection were studied on referral to our unit. All patients were anti-HCV positive by enzyme linked immunosorbent assay (ELISA) and were confirmed positive by RIBA 2 immunoblotting. None of the patients had been previously treated with antiviral drugs or had other potential causes of liver disease, such as alcoholism, autoimmune phenomena, or metabolic disorders. Percutaneous liver biopsy was performed for diagnostic purposes in all patients and in 21 , including seven with undetectable serum HCV RNA by polymerase chain reaction (PCR), part of the bioptic fragment was used for histological analysis, while part (median weight $4.2 \mathrm{mg}$, range $1-9.3 \mathrm{mg}$ ) was snap frozen in liquid nitrogen and stored at $-80^{\circ} \mathrm{C}$ for simultaneous quantitative assessment of HCV RNA in the liver and in the corresponding serum sample. Histological diagnosis was consistent with chronic liver disease in all patients. Grading of histological features was performed according to Desmet et $a l^{10}$ and showed features of minimal chronic hepatitis (CH) in two patients, mild $\mathrm{CH}$ in 29 , moderate $\mathrm{CH}$ in 49 , and severe $\mathrm{CH} /$ cirrhosis in 16 . The liver biopsy specimens were evaluated by one pathologist who was unaware of the clinical, biochemical, and virological data.
LABORATORY TESTS

HBsAg, anti-HBc, and anti-HIV were tested for using commercially available kits. AntiHCV was detected by second generation ELISA (Ortho Diagnostic, Raritan, New Jersey, USA) and confirmed by immunoblotting (RIBA 2, Chiron Corporation, Emeryville, California, USA).

The level of HCV RNA was determined in serum and liver biopsy samples using a commercially available branched DNA (bDNA) amplification assay (Quantiplex HCV RNA assay, Chiron Corporation). Serum samples negative 


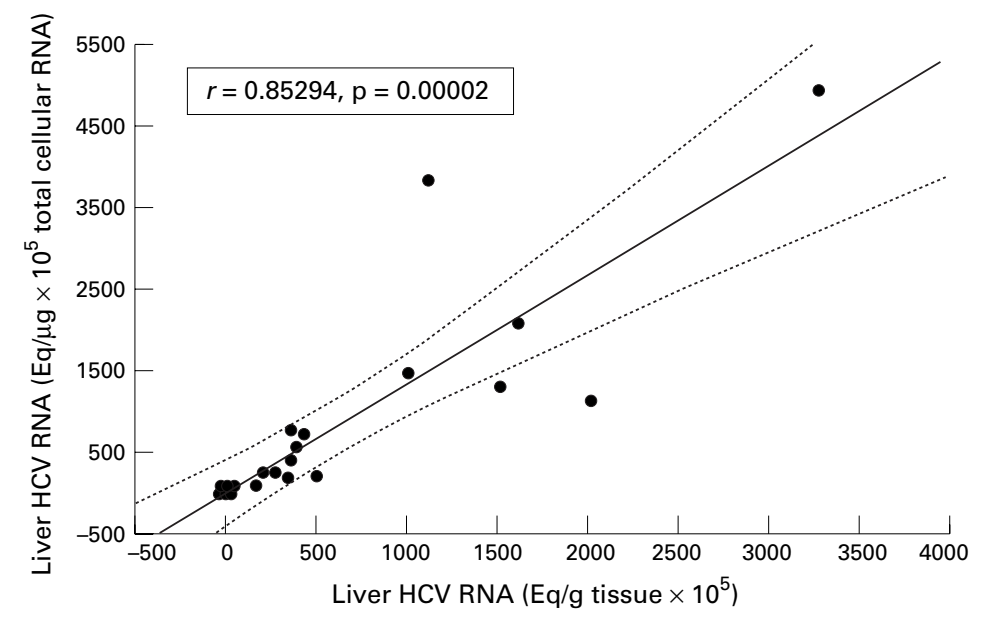

Figure 1 Relation between amount of HCV RNA in the liver expressed as Eq/g of tissue and Eq/ug of total cellular RNA.

by the bDNA assay were retested by reverse transcription-polymerase chain reaction (RTPCR) in order to identify low levels of HCV genomic sequences, not detectable with the above system. ${ }^{11}$

Qualitative detection of HCV RNA by RT-PCR $\mathrm{HCV}$ RNA was determined directly from serum by nested polymerase chain reaction in a single tube assay, after reverse transcription (RT-PCR), using primers derived from the $5^{\prime}$ non-translated region (5'-UTR), to reduce chances of cross contamination, as previously described. ${ }^{12}$ Briefly, $3 \mu$ of serum was mixed with $11 \mu \mathrm{l}$ of buffer containing $10 \mathrm{mM}$ Tris- $\mathrm{HCl}$ ( $\mathrm{pH}$ 8.4), $50 \mathrm{mM} \mathrm{KCl,} 2.5 \mathrm{mM}$ $\mathrm{MgCl}_{2}, 1 \mathrm{mM}$ of the four dNTPs (Boehringer, Mannheim, Germany), 20 U of RNAsin (Boehringer), and $50 \mathrm{pmol}$ of the antisense external primer, and heat treated for 30 seconds at $94^{\circ} \mathrm{C}$. After quick chilling, $10 \mathrm{U}$ of murine myeloblastosis virus reverse transcriptase (Gibco BRL, Milan, Italy) was added and

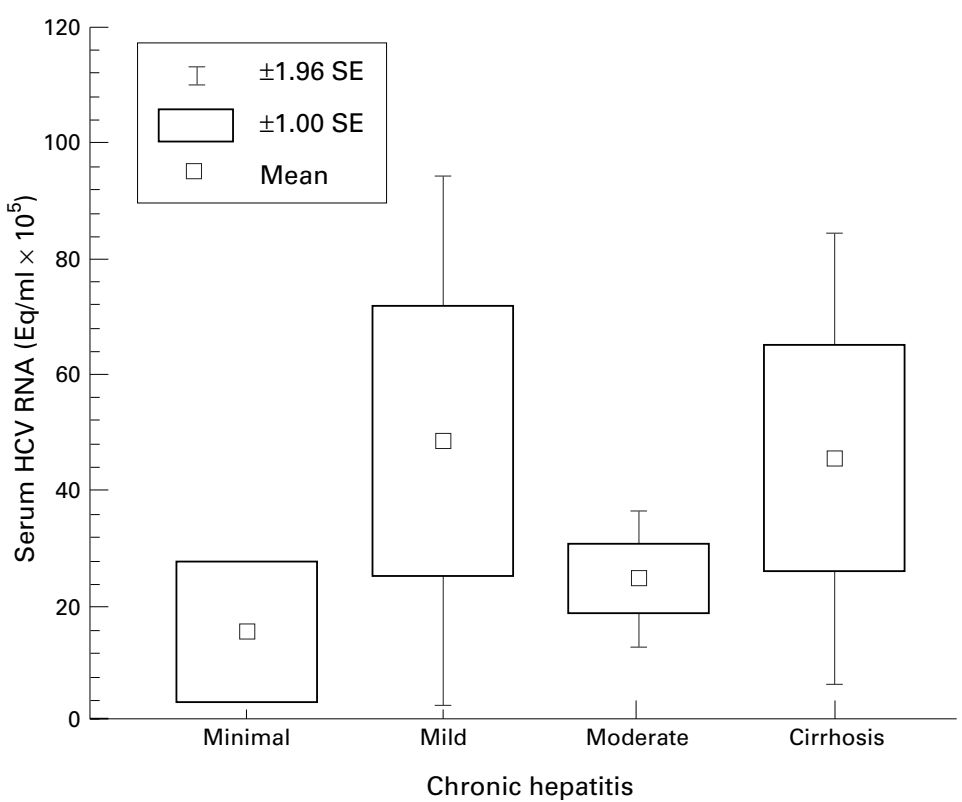

Figure 2 Viral load detected in serum in anti-HCV positive patients in relation to histological diagnosis. incubated for one hour at $37^{\circ} \mathrm{C}$. All $15 \mu \mathrm{l}$ of cDNA was used for the first amplification in a reaction volume of $50 \mu \mathrm{l}$ containing $10 \mathrm{mM}$ Tris- $\mathrm{HCl}, 1.5 \mathrm{mM} \mathrm{MgCl}, 50 \mathrm{mM} \mathrm{KCl}, 0.2$ $\mathrm{mM}$ of each dNTP, $2.5 \mathrm{U}$ of Taq DNA polymerase (Boehringer), and 5 pmol of each external primer, and was added to $350 \mu \mathrm{l}$ of silicone oil (Fluka, Chemika, Switzerland). The second step mixture of $150 \mu$ containing $10 \mathrm{mM}$ Tris- $\mathrm{HCl}, 1.5 \mathrm{mM} \mathrm{MgCl}_{2}, 50 \mathrm{mM}$ $\mathrm{KCl}, 0.2 \mathrm{mM}$ of each dNTP, and $50 \mathrm{pmol}$ of internal primers was loaded over the silicone oil. After the first step of amplification consisting of one cycle of one minute at $94^{\circ} \mathrm{C}$, one minute at $50^{\circ} \mathrm{C}$, and one minute at $72^{\circ} \mathrm{C}$, and 25 cycles at $94^{\circ} \mathrm{C}$ for 45 seconds, $50^{\circ} \mathrm{C}$ for 45 seconds, and $72^{\circ} \mathrm{C}$ for 45 seconds, the tubes were centrifuged for one minute at $4000 \mathrm{rpm}$ to precipitate the upper mixture. For the second round of amplification 28 cycles at the above conditions were performed. The amplified products were visualised by ethidium bromide staining after electrophoresis in a $1.5 \%$ agarose gel. Water and serum from normal healthy subjects were used as controls. All reagents were treated with ultraviolet light and positive displacement pipettes (Eppendorf, Hamburg, Germany) were used to minimise contamination. Starting with direct amplification of $3 \mu \mathrm{l}$ of serum, the detection limit of the assay was 10000 genome equivalents $/ \mathrm{ml}$, as reported previously. ${ }^{12}$

\section{HCV RNA quantitation}

Serum-HCV RNA was quantitated in serum by a signal amplification test using a bDNA assay based on specific hybridisation of virus RNA present in the sample with synthetic oligonucleotides derived from the 5'-UTR region and core region of HCV RNA, immobilised on a microwell plate (Quantiplex Version 1.0). Synthetic bDNA amplifier molecules and multiple copies of alkaline phosphatase linked probe were hybridised to the immobilised complex and incubated with a chemiluminescent substrate, the luminescent signal being proportional to the level of target nucleic acid. The quantity of HCV RNA in the sample was then determined from a standard curve. The detection limit of this technique has been calculated to be 350000 viral equivalents $/ \mathrm{ml}$ $(\mathrm{Eq} / \mathrm{ml}){ }^{11}$ Each serum sample was run in duplicate using $50 \mu \mathrm{l}$ of serum per assay and if the coefficient of variation between the two measurements was greater than $20 \%$, the assay was repeated. In our working conditions this event occurred for only one sample.

Liver-HCV RNA levels were detected in liver specimens after extraction of total cellular RNA using a previously standardised method. ${ }^{13}$ Briefly, biopsy samples were weighed and then rapidly homogenised in $8 \mathrm{M}$ cold guanidine hydrochloride and $0.5 \%$ sarcosyl using disposable pestles and matched tubes (Kontes Corp., Vineland, New Jersey). RNA in the homogenised samples was selectively precipitated with $0.5 \times$ volume $100 \%$ chilled ethanol in the presence of $0.2 \%$ glycogen, washed once in $70 \%$ chilled ethanol, and dried using a rotary vacuum device. The pellet 
Table 1 HCV RNA detected in serum and in the corresponding liver in 21 anti-HCV positive patients

\begin{tabular}{lllc}
\hline & & \multicolumn{2}{l}{$H C V$ RNA by bDNA in the liver } \\
\cline { 3 - 4 } Serum HCV RNA & No & Negative & Positive \\
\hline PCR negative & 7 & 6 & 1 \\
PCR postive/bDNA negative & 5 & 0 & 5 \\
PCR postive/bDNA positive & 9 & 0 & 9 \\
\hline
\end{tabular}

was resuspended in $20 \mu \mathrm{l}$ of waterdiethylpyrocarbonate with $0.5 \mu \mathrm{l}$ RNAsin added. A $10 \mu \mathrm{l}$ aliquot of the precipitate was resolubilised in $330 \mu \mathrm{l}$ extraction buffer containing proteinase $\mathrm{K}$ and sodium dodecyl sulphate (SDS), provided by the manufacturer and directly added to a 96 well plate for bDNA assay, while $10 \mu \mathrm{l}$ was used for spectrophotometric analysis and quantitation of total cellular RNA.

To validate the working conditions in our laboratory, we have compared the results obtained measuring the wet weight of the liver specimen with those obtained measuring the recovered total cellular RNA. As shown in fig 1 , a good correlation $(r=0.85)$ between viral load in the liver expressed as Eq/g of liver tissue or $\mathrm{Eq} / \mu \mathrm{g}$ of total cellular RNA was obtained, indicating that in our working conditions the expression of the results per $g$ of liver tissue was adequate, not being influenced by the efficiency of total cellular RNA extraction from each specimen.

Genomic heterogeneity, typical of the different $\mathrm{HCV}$ genotypes ${ }^{14}$ can affect the efficiency of hybridisation and consequently of HCV RNA detection with this version of the bDNA assay in the presence of viral sequences other than those of genotype 1 , for which the assay was standardised. Therefore, the bDNA results in both serum and liver were corrected for genotype by multiplying by three the values obtained in samples of patients infected with genotype 2, and by two those of patients infected with genotype 3 , as suggested. ${ }^{15}$

HCV GENOTYPING

To identify HCV genotypes, we used a dot blot assay, previously standardised in our laboratories ${ }^{16}$ in which the products of PCR

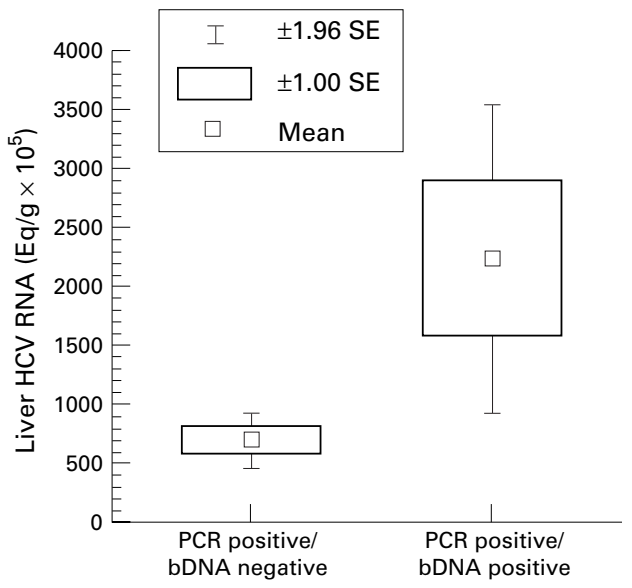

Figure 3 Viral load in the liver in patients with $\mathrm{HCV}$ $R N A$ detectable in the corresponding serum only by PCR and in those with viraemia detectable also by bDNA. amplification, immobilised on nylon filters, were hybridised with oligonucleotide probes specific for different HCV genotypes. The probes, derived from the variable sequence of the 5'-UTR (from nucleotide 135 to nucleotide 155), were $3^{\prime}$ end labelled with fluoresceindUTP and specific hybridisation revealed by the enhanced chemiluminescent method (ECL, Amersham International, Amersham, UK). Prehybridisation was carried out at $42^{\circ} \mathrm{C}$ for one hour, followed by a two hour hybridisation at $42^{\circ} \mathrm{C}$. Washes were carried out in stringent conditions: twice with $5 \times$ saline sodium citrate (SSC), $0.1 \%$ SDS at room temperature for 10 minutes; twice with $1 \times S S C, 0.1 \%$ SDS at $56^{\circ} \mathrm{C}$ for 20 minutes; and once with $0.1 \times$ SSC, $0.1 \%$ SDS at $56^{\circ} \mathrm{C}$ for 10 minutes. Hybridised probes were then detected in a two stage process: development of the fluorescein hapten by incubation with an antifluorescein horseradish peroxidase (HRP) conjugate; detection of bound peroxidase using the ECL detection reagents, followed by autoradiography. ${ }^{12}$

\section{STATISTICAL ANALYSIS}

The Kruskal-Wallis test for continuous variables and the Spearman test were used as nonparametric statistical methods. To represent levels of viral load in different groups in both serum and liver the box and whisker plot model was used.

\section{Results}

Eighty nine patients were HCV RNA positive in serum by PCR of which 52 had detectable levels of HCV RNA by the bDNA assay, which was positive in $72 \%$ of patients infected by genotype $1,44 \%$ of those infected by genotype 2 , and $21 \%$ of those infected by genotype 3 . In these patients no correlation was observed between available levels of viraemia and age of the patient $(r=0.35)$ or serum alanine aminotransferase (ALT) activity, determined at the same time $(r=-0.03)$. In addition, as shown in fig 2 , no correlation was found between viraemic levels and histological findings $(p=0.58)$, although the limited number of patients with minimal $\mathrm{CH}$ did not allow exclusion of the possibility that a low viral burden may exist in a subgroup of patients with very mild $\mathrm{CH}$.

Table 1 presents a comparison of HCV RNA measurement in serum and in the corresponding liver biopsy specimen in 21 anti-HCV positive patients. Overall 14 patients were $\mathrm{HCV}$ RNA positive in serum by PCR and in nine of them viraemia exceeded the detection limit of the quantitative bDNA assay. Liver HCV RNA was detectable by bDNA assay in 15 patients, including all those with high viraemic levels (greater than $3.5 \times 10^{5} \mathrm{Eq} / \mathrm{ml}$ ); in five patients it was positive in serum only by PCR, and in one additional patient HCV RNA could not be detected in serum either by bDNA or by PCR.

Figure 3 shows mean virus load in liver in relation to the results of HCV RNA detection in serum. Patients with low viraemic levels, not detectable by the bDNA assay, had mean liver 
values of HCV RNA lower that those found in patients with viraemic values higher than $3.5 \times$ $10^{5} \mathrm{Eq} / \mathrm{ml}$.

Mean liver HCV RNA levels were similar in patients infected by HCV 1 (mean (SD) 2037.7 (1964.3) Eq/g) or by HCV 2 (1627.2 (1622.3) Eq/g), while of the two patients infected by HCV 3, one was bDNA negative and the other had $684 \times 10^{5} \mathrm{Eq} / \mathrm{g}$ of HCV RNA in the liver.

\section{Discussion}

The polymorphic features of HCV infection are determined by both host and viral factors, although the precise mechanisms are not yet fully identified. Genomic analysis and sequence comparison has allowed the classification of $\mathrm{HCV}$ into different genotypes ${ }^{14}$ and a preferential association of genotype 1 with more severe forms of liver disease has been described, ${ }^{17}{ }^{18}$ while genotype 2 has been found in the majority of asymptomatic $\mathrm{HCV}$ carriers. ${ }^{19}{ }^{20}$ However, in other studies in which large groups of anti-HCV positive patients with chronic liver disease have been studied, no clinical or histological differences could be identified among patients infected with different genotypes. ${ }^{112122}$ Another parameter that might be related to the pathogenesis of liver damage is viral load. To address this point several quantitative and semiquantitative methods have been devised, their main limitation being the lack of standardisation and, consequently comparison of results is difficult. ${ }^{112324}$ The signal amplification technique has helped to overcome this limitation and the corrected formulation of the results, which takes into consideration the infecting genotype, ${ }^{15}$ allows a more precise definition of viral replicative activity. Whether HCV RNA levels detected in serum parallel the amount of virus in the liver is still a matter of debate. ${ }^{7813}$ Crucial methodological points are the efficiency of RNA extraction and viral detection conditions. In the present study we have shown that viral load in serum substantially reflects the amount of virus in the liver. Lower levels in liver samples were indeed found in cases in which the corresponding serum HCV RNA was lower than the detection limit of the bDNA assay and, conversely, higher HCV RNA levels in the liver were found in patients with viraemic values above $3.5 \times 10^{5} \mathrm{Eq} / \mathrm{ml}$.

No correlation between viral load and degree of liver injury was found in the present study. Controversial reports have been published on this point; in some studies high titre viraemia was correlated with advanced stage liver disease, ${ }^{525}$ while others found no correlation with either histology or aminotransferase activities. ${ }^{26}$ In addition, in most of the studies in which the intrahepatic HCV RNA level was evaluated, no correlation with liver injury was shown. ${ }^{77}{ }^{28}$ It should be noted that the characteristics of the population studied are important variables for the interpretation of the results, since significant differences were only observed when extremely different clinical settings were considered, for example, asymptomatic HCV carriers versus end stage liver disease. ${ }^{525}$ In the present paper the study population included patients with disease severity ranging from mild chronic hepatitis to liver cirrhosis; there were only a few cases with minimal features of hepatitis. It is possible that the wide range in viral load detected in individual patients does not allow identification of any difference, unless extreme situations are considered. On the other hand, the putative mechanism of liver injury is not yet fully clarified. While the contribution of a direct cytopathic effect of $\mathrm{HCV}$ to liver damage is still controversial, several lines of evidence, including the existence of chronic $\mathrm{HCV}$ infections without clinically overt disease ${ }^{29}$ and the detection of diffuse viral antigens in the liver of immunosuppressed transplant patients, ${ }^{30}$ indicate that immune mediated mechanisms, already described for hepatitis $B$ virus infection, ${ }^{31}$ are likely to play an important role in the pathogenesis of hepatitis C. However, at variance with hepatitis $B$, where impairment of the virus specific $\mathrm{T}$ cell response has been observed, ${ }^{32}$ in patients with hepatitis $\mathrm{C}$ a valid $\mathrm{T}$ cell response to $\mathrm{HCV}$ proteins has been detected both in the liver ${ }^{33}$ and in the peripheral blood lymphocytes. ${ }^{34}{ }^{35}$ Whether the level of viral load is the result of immune surveillance or whether it acts as an independent variable awaits the development of reliable cell culture systems.

The authors are grateful to Dr P J Dailey (Chiron Corporation, Emeryville, California) for his contribution to liver biopsy processing and viral load determination.

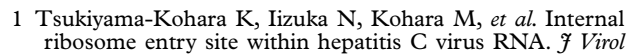
1992;66:1476-83.

2 Wang C, Le SY, Ali N, Siddiqui A. An RNA pseudoknot is an essential structural element of the internal ribosome entry site located within the hepatitis $\mathrm{C}$ virus 5 ' non coding region. RNA 1995;1:526-37.

3 Lau JYN, Davis GL, Kniffen J, et al. Significance of serum hepatitis C virus RNA levels in chronic hepatitis C. Lancet 1993;341:1501-4.

4 Naito M, Hayashi N, Hagiwara H, et al. Serum hepatitis C virus RNA quantity and histological features of hepatitis $C$ virus carriers with persistently normal ALT levels. Hepatolvirus carriers with p
ogy 1994;19:871-5.

ogy 1994;19:871-5.
5 Gretch DR, Corey L, Wilson J, et al. Assessment of hepatitis $C$ virus RNA levels by quantitative competitive RNA polymerase chain reaction: high-titer viremia correlates with advanced stage of disease. F Infect Dis 1994;169:121925

6 Gretch DR, dela Rosa C, Carithers RL Jr, et al. Assessment of hepatitis C viremia using molecular amplification technologies: correlation and clinical implications. Ann Intern Med 1995;123:321-9.

7 Coelho-Little E, Jeffers LJ, Bartholomew M, et al. Correlation of HCV-RNA levels in serum and liver of patients with chronic hepatitis C. F Hepatol 1995;22:508.

8 Francesconi R, Manzin A, Giostra F, et al. Quantitation of liver HCV-RNA: relation to number of HCV infected liver HCV-RNA: relation to number of HCV infected
hepatocytes, HCV genotypes, HCV viremia and response hepatocytes, HCV genotypes, HCV viremia and response

9 Yatsuhashi H, Inoue O, Koga M, et al. Correlation between Yatsuhashi $\mathrm{H}$, Inoue $\mathrm{O}$, Koga $\mathrm{M}$, et al. Correlation between
serum and liver tissue HCV-RNA levels in patients with chronic hepatitis C. Int Hepatol Commun 1995;3:35-40.

10 Desmet VJ, Gerber M, Hoofnagle JH, et al. Classification of chronic hepatitis: diagnosis, grading and staging. Hepatology 1994;19:1513-20.

11 Urdea MS, Horn T, Fultz TJ, et al. Branched DNA amplification multimers for the sensitive, direct detection of human hepatitis viruses. Nucleic Acids Research Symposium Series no. 24. Oxford: Oxford University Press, 1991:197-200.

12 Pontisso P, Ruvoletto MG, Nicoletti M, et al. Distribution of three major hepatitis $\mathrm{C}$ virus genotypes in Italy. A multicentre study of 495 patients with chronic hepatitis C. f Viral Hepatol 1995;2:33-8.

13 Terrault NA, Dailey PJ, Ferrel L, et al. Hepatitis C virus: quantitation and distribution in liver. F Med Virol 1997;51: 217-24.

14 Simmonds P. Variability of hepatitis C virus. Hepatology 1995;21:570-83.

15 Lau JYN, Simmonds P, Urdea MS. Implications of variation of "conserved" regions of hepatitis C virus genome. Lancet 1995;346:425-6. 
16 Tisminetzky SG, Gerotto M, Pontisso P, et al. Genotypes of hepatitis $\mathrm{C}$ virus in Italian patients with chronic hepatitis C. Int Hepatol Commun 1994;2:105-12.

17 Nousbaum JB, Pol S, Nalpas B, et al. Hepatitis C virus type 1b (II) infection in France and Italy. Ann Intern Med 1995; 122:161-8.

18 Kobayashi $M$, Tanaka E, Sodeyama $T$, et al. The natural course of chronic hepatitis C: a comparison between patients with genotype 1 and 2 hepatitis $C$ viruses. Hepatology 1996;23:695-9.

19 Silini E, Bono F, Cividini A, et al. Differential distribution of hepatitis C virus genotypes in patients with and without liver function abnormalities. Hepatology 1995;21:285-90.

20 Prati D, Capelli C, Zanella A, et al. Influence of different hepatitis $C$ virus genotypes on the course of asymptomatic hepatitis C virus infection. Gastroenterology 1996;110:17883.

21 Yamada M, Kakumu S, Yoshioka K, et al. Hepatitis C virus genotypes are not responsible for the development of serigenotypes are not responsible for the developm
ous liver disease. Dig Dis Sci 1994;39:234-9.

22 Lau JYN, Davis GL, Prescott LE, et al. Distribution of hepatitis $\mathrm{C}$ virus genotypes determined by line probe assay in patients with chronic hepatitis $\mathrm{C}$ seen at tertiary referra centers in the United States. Ann Intern Med 1996;124 $868-76$.

23 Kaneko S, Murakami S, Unoura M, et al. Quantitation of hepatitis $\mathrm{C}$ virus RNA by competitive polymerase chain reaction. f Med Virol 1992;37:278-82.

24 Manzin A, Bagnarelli P, Menzo S, et al. Quantitation of hepatitis $\mathrm{C}$ virus genome molecules in plasma samples. $\mathcal{F}$ Clin Microbiol 1994;32:1939-44.

25 Hagiwara H, Hayashi N, Mita E, et al. Quantitation of hepatitis $\mathrm{C}$ virus $\mathrm{RNA}$ in serum of asymptomatic blood donors and patients with type $\mathrm{C}$ chronic liver disease. Hepatology 1993;17:545-50.
26 Chayama K, Tsubota A, Arase Y, et al. Quantitative analysis of hepatitis C virus RNA by competitive nested polymerase chain reaction. F Gastroenterol Hepatol 1993;8:S40-4.

27 Sakamoto N, Enomoto K, Kurosaki M, et al. Detection and quantitification of hepatitis $C$ virus RNA replication in the liver. F Hepatol 1994;20:593-7.

28 McGuiness P, Bishop A, Painter DM, et al. Intrahepatic hepatitis C RNA levels do not correlate with degree of liver injury in patients with chronic hepatitis C. Hepatology injury in patients

29 Brillanti S, Foli M, Gaiani C, et al. Persistent hepatitis C viraemia without liver disease. Lancet 1993;341:464-5.

30 Krawczynski K, Beach MJ, Bradley DW, et al. Hepatitis $C$ virus antigen in hepatocytes: immunomorphologic detection and identification. Gastroenterology 1992;103: $622-9$.

31 Thomas HC, Jacyna M, Waters J, et al. Virus-host interaction in chronic hepatitis B virus infection. Semin Liv Dis 1988;8:342-9.

32 Barnaba V, Balsano F. Immunologic and molecular basis of viral persistence. The hepatitis B virus model. F Hepatol 1992;14:391-400

33 Koziel MJ, Dudley D, Wong J, et al. Intrahepatic cytotoxic T lymphocytes specific for hepatitis $\mathrm{C}$ virus in persons with chronic hepatitis. F Immunol 1992;149:3339-44.

34 Ferrari C, Valli A, Galati L, et al. T-cell response to structural and nonstructural hepatitis $\mathrm{C}$ virus antigens in persistent and self-limited hepatitis C virus infection. Hepatology 1994;19:286-95. 35 Cerny A, McHutchison JG, Pasquinelli C, et al. Hepatitis C
virus specific cytotoxic T cell response: identification of multiple HLA-2 restricted epitopes. F Clin Invest 1995;95: 521-30. 